\title{
Polymer-modified tailings deposition - ongoing testing and potential storage efficiency opportunities
}

\author{
TC Riley Golder Associates Pty Ltd, Australia \\ D Reid Golder Associates Pty Ltd, Australia \\ L Utting BASF Australia Ltd, Australia
}

\begin{abstract}
An emerging technology, known by various names such as in-line flocculation, polymer modified tailings deposition or more commercially as enhanced tailings disposal (ETD), is the subject of growing interest from mining operations. Business drivers for the mine tailings facility owners can include a variety of site-specific, material-dependant operational challenges, as well as more general desires to improve efficiency at tailings storage facilities (TSFs).

Polymers can modify the behaviour of tailings in a variety of ways; one of these is through rheological adjustment. This can often result in a steepened beach which, with careful design and use of natural or man-made landforms, can result in the potential for significant reduction in the volume of initial embankment construction material. These opportunities are the subject of a number of ongoing large-scale operational trials that are likely to become the topic of future papers.
\end{abstract}

Other material behavioural changes are inextricably linked with the technology. These include reduced segregation, improved water release, less long-term settlement, and improving permeability and subsequent consolidation behaviour. Thorough understanding of these improvements can allow for appropriate design and operational management, which can then allow the operator leverage to improve long-term operational performance.

This paper describes some scoping-level testing that focused on potential time-related opportunities that may lead to more efficient tailings management. Subject to site-specific constraints, there may be a costeffective opportunity to defer future capital expenditure required for construction of a subsequent facility, or construction of the next raise of the embankments. Increased consolidation rates may also lead to improved trafficability and thus more efficient rehabilitation. Whilst not going into specific detail concerning operational or construction costs, this paper presents high-level results of testing and consolidation modelling, demonstrating a combination of opportunities for improved tailings performance through the implementation of the following:

- Accelerating and increasing overall water release.

- Improving the rate of consolidation.

- Reducing the rate of rise.

- Reducing the amount of post depositional settlement.

The implications of the data and modelling are discussed in the context of potential business opportunities, which can be broadly described as the 'time value of volume'.

\section{Introduction}

For the purposes of simplicity, the process known variously as in-line flocculation, polymer modified tailings deposition or, more commercially, as enhanced tailings disposal (ETD), will be termed polymer treatment or simply as treatment in this paper. 
Although some projects may benefit from a steepened beach concept to reduce the early capital cost of embankment construction through the use of polymer treatment, other projects may benefit from the process in other ways (Dymond 2003; Kaiser et al. 2006; Adkins et al. 2007; Brumby et al. 2008; Vietti et al. 2008; Daubermann \& Földvári 2008, 2009; da Silva 2011; Riley \& Utting 2014).

Polymer treatment modifies tailings deposition in a number of inter-related ways. Polymers with specific chemistry, selected to match tailings mineralogy and process water, may significantly modify settlement and consolidation rates. This is achieved in part by processes not dissimilar to flocculation, but progresses into the formation of a fabric (Wells 2011) that facilitates water release and consolidation within the deposited tailings.

In combination with reduced particle segregation, it is becoming apparent that higher densities and consolidation rates, when realised, may make more efficient use of available storage volume in a given timeframe. Alternatively, when there is an imposed time dependency to achieve other objectives such as rehabilitation or removal of material to a more permanent TSF, a significant business improvement opportunity may exist. The existence of a demonstrable opportunity is considered a prerequisite for testing.

This paper outlines the laboratory testing and consolidation modelling of samples of copper, mineral sands and copper/gold tailings from three different active mining projects. At each site, polymer treatment was either under consideration or already underway, but requiring an increased level of technical rigour. The results of this work were used to provide input to the potential use of the process or the implications of different polymer dosages onsite outcomes.

\section{Experimental and modelling techniques}

\subsection{Laboratory testing}

Laboratory testing outlined herein typically comprises settling and slurry consolidometer tests (Sheeran \& Krizek 1971). Settling tests were typically undertaken with undrained, top drained, bottom drained, and double (top and bottom) drained boundary conditions, to provide an assessment of solids/liquid separation behaviour under different conditions. It is acknowledged that the relatively small diameter of the settling tubes may influence settling behaviour of the material and that such settling tests can only be considered as an indicator test to assess some of the processes occurring within a tailings deposit.

Slurry consolidometer testing was undertaken in $71 \mathrm{~mm}$ diameter columns, with top drainage of the sample. Constant head permeability tests were undertaken at the end of most loading stages.

Of the material tested in this study, the copper and copper/gold tailings were tested from a single client-supplied sample. Material was sub-sampled when needed to undertake laboratory scale treatment testing. This technique enables a direct comparison to be made of the effects of polymer treatment, without material variability influencing results. For the mineral sands tailings, this was not possible. The reasons for this, and potential implications as they related to the results for that material, are discussed in the following sections.

\subsection{Consolidation modelling}

Following laboratory characterisation, numerical consolidation models were developed to assess the implications of polymer treatment, or of different polymer dosages, based on specific site conditions. The models were developed using the finite strain code CONDESO (Yao \& Znidarcic 1997). Finite strain models enable many of the salient features of tailings consolidation to be simulated, including incremental deposition, significant variation in material properties with stress, and the relatively large displacements typical of self-weight consolidation. They provide a more robust analysis of self-weight consolidation problems when compared to small-strain analysis techniques (e.g. Schiffman et al. 1984). 
Consolidation models were developed for idealised one-dimensional columns of material, representing an average depositional rate of rise and depth of deposited tailings for the site under consideration. Depositional rate of rise is used herein to describe the appropriate input to an incremental consolidation model, which is based on production rate, depositional area geometry, and (where relevant) settled density of the material. It is noted that such idealisations cannot capture the variety of behaviour across a typical tailings cell. Rather, they enable comparison of the implications of different sets of material parameters to be investigated in a consistent manner. As a result of such a modelling process, the average 'field rate of rise' can be inferred, which is the predicted rate of rise of the tailings when including density increases through consolidation.

\section{Polymer-treatment effects on consolidation behaviour}

The primary effects of treatment to the current study have the potential to result in an increased rate of initial dewatering and increased rate of self-weight consolidation. Where this effect is observed, it offers the potential for a higher average in situ dry density to be realised, the potential for faster remediation of a tailings surface, and increased water recovery.

It is noted that while in some instances polymer treatment of tailings appears to result in a lower final density during consolidation (Jeeravipoolvarn et al. 2009, 2010; Yao 2012; Reid \& Fourie 2012, 2014), a faster rate of consolidation can in some situations result in a higher average in situ dry density during deposition. Alternatively, there are instances where polymer treatment resulted in both significantly higher final densities during consolidation (Azam 2011) and permeability at a given density.

The laboratory testing outlined in this study suggests that polymer treatment can induce significant beneficial changes in some materials, with respect to rate of consolidation. To provide context on these results, a series of examples from the literature are presented in Table 1, where polymer addition or other changes in soil fabric resulted in significantly different material behaviour, with respect to density or rate of consolidation.

Table 1 Observed effects of polymer treatment or fabric change on consolidation

\begin{tabular}{|c|c|c|c|}
\hline Reference & Trigger for changes & $\begin{array}{l}\text { Variation in } \\
\text { density* }\end{array}$ & $\begin{array}{l}\text { Variation in rate of } \\
\text { consolidation or permeability }\end{array}$ \\
\hline $\begin{array}{l}\text { Mathew and Narashimha } \\
\text { (1997) }\end{array}$ & Pore fluid chemistry & $15 \%$ & Not reported \\
\hline Wang and Siu (2006) & Pore fluid chemistry & $10 \%$ & Not reported \\
\hline $\begin{array}{l}\text { Sachan and Penumadu } \\
\text { (2007) }\end{array}$ & Pore fluid chemistry & $20 \%$ & Three times lower \\
\hline Inparajah and Wong (2008) & Pore fluid chemistry & $75 \%$ & Not reported \\
\hline Jeervipoolvarn et al. (2009) & Polymer treatment & Negligible & $\begin{array}{c}\text { Permeability three orders of } \\
\text { magnitude larger at low } \\
\text { stresses }\end{array}$ \\
\hline Chang et al. (2011) & Sample preparation & Negligible & $c_{v}$ three times greater \\
\hline Pillai et al. (2011) & Pore fluid chemistry & Negligible & $\begin{array}{l}\text { Permeability doubled at the } \\
\text { same void ratio }\end{array}$ \\
\hline Amarasinghe et al. (2012) & Pore fluid chemistry & $7 \%$ & One order of magnitude \\
\hline Azam (2011) & Polymer treatment & $\begin{array}{c}100 \% \text { at } 10 \mathrm{kPa} \\
\text { vertical stress }\end{array}$ & $\begin{array}{l}\text { Permeability one order of } \\
\text { magnitude larger or smaller, } \\
\text { dependent on polymer used }\end{array}$ \\
\hline Yao (2012) & Polymer treatment & 5\% lower & Negligible \\
\hline
\end{tabular}

* Variation at $100 \mathrm{kPa}$ vertical effective stress, unless otherwise noted 
It can be seen from the previous studies presented that significant changes to the consolidation properties of a soil can be expected following polymer treatment, or other changes to soil fabric induced through pore fluid chemistry. It is noted that the changes induced by pore fluid chemistry often larger than most of those resulting from polymer treatment. It is the authors' opinion that further comparisons could be conducted in this area, looking at direct comparisons between polymer soil treatment and pore water chemistry changes, using the same substrate.

\section{$4 \quad$ Business context and scoping level testing with interpretation}

\subsection{A copper mining operation}

\subsubsection{Site description}

The site utilises conventional cellular TSF design. As a result of climate and an inability to discharge excess water, rate of rise of tailings is a significant business issue, compounded by other factors such as adverse terrain. Increasing the settling and subsequent consolidation rate are considered beneficial, as is more rapid clarification of supernatant water. The challenge at this site is to defer/avoid the construction of an embankment raise.

\subsubsection{Copper tailings testing, results and interpretation}

The work comprised settling and slurry consolidometer testing on a client-supplied sample of slurry at a density of $24 \%$ solids by mass, consistent with typical material deposited onsite. The material was predominately silt-sized, with $86 \%$ passing $75 \mu \mathrm{m}$, and $11 \%$ clay-sized.

The following observations were apparent, based on the test results:

- While settled densities for untreated material were typically higher than treated samples, upon application of vertical loads, the treated samples appear to achieve higher densities. This may be a result of a more compressible fabric induced by treatment which, at low stresses, results in a greater increase in density over a given increment of stress compared to untreated samples.

- Treated material is generally of higher permeability than untreated material across a wide range of vertical effective stresses.

The interactions of settling and consolidation results on material behaviour in situ were assessed with an incremental consolidation model using an average depositional rate of rise observed onsite.

Models were developed for untreated slurry and at dosages of 75 and $392 \mathrm{~g} / \mathrm{t}$ respectively to represent either end of the potential polymer dosing spectrum for this material. The model simulated tailings deposition over a period of 10 years, followed by a fallow period until post-deposition settlement ceased. Models were prepared based on idealised columns of tailings. The results of the consolidation modelling are summarised in Table 2.

It is noted that the recovered percentages of water appear high for all scenarios presented. This is a result of the relatively low depositional solids content, which results in significant quantities of liberated water after initial settling. 
Table 2 Consolidation model results for copper tailings

\begin{tabular}{lccccc}
\hline \multicolumn{1}{c}{ Model output } & & Units & Untreated & $\mathbf{7 5 ~} \mathbf{~ / t}$ & $\mathbf{3 9 2} \mathbf{~ g / t}$ \\
\hline & 1 year & $\mathrm{t} / \mathrm{m}^{3}$ & 0.73 & 0.92 & 0.89 \\
Average dry density & 5 year & $\mathrm{t} / \mathrm{m}^{3}$ & 0.82 & 1.04 & 1.04 \\
& 10 year & $\mathrm{t} / \mathrm{m}^{3}$ & 0.85 & 1.09 & 1.10 \\
Depth of tailings by time & 1 year & $\mathrm{m}$ & 3.4 & 2.7 & 2.8 \\
& 5 year & $\mathrm{m}$ & 15.4 & 11.8 & 12 \\
& 10 year & $\mathrm{m}$ & 29.6 & 21.7 & 22.4 \\
Percentage of water recovered* & 1 year & $\%$ & $70 \%$ & $79 \%$ & $78 \%$ \\
& 5 year & $\%$ & $75 \%$ & $83 \%$ & $82 \%$ \\
Average in situ rate of rise over 10 years & 10 year & $\%$ & $76 \%$ & $85 \%$ & $84 \%$ \\
Post-deposition settlement & & $\mathrm{m} / \mathrm{y}$ & 3 & 2.2 & 2.2 \\
Time for completion of post-deposition settlement & Years & 17.4 & 4.1 & 5.2 \\
\hline
\end{tabular}

In terms of dose rate, a 'sweet spot' is commonly apparent. In this case, there would appear to be little, if any, gain from the higher dose rate. Table 2 suggests that across a range of suitable metrics and timeframes, treatment at the lower dose rate could improve depositional performance by the following:

- Increasing self-weight consolidation rate.

- Reducing the actual rate of rise.

- Releasing more water.

- Reducing the time to complete post-depositional settlement.

\subsubsection{Summary for copper tailings project}

The results suggest that polymer treatment may reduce the in situ rate of rise from 3 to $2.2 \mathrm{~m} /$ year over a ten-year period, potentially realising a $26 \%$ saving in the effective utilisation of constructed storage volume.

\subsection{A mineral sands operation}

\subsubsection{Site description}

The operation produces a heavy metals concentrate comprising zircon, ilmenite and rutile from shallow, linear orebodies. The deposit is extracted by a method known as 'shallow strip mining', a continuous mining process in a given direction of advance using a combination of scrapers, bulldozers and front-end loaders.

As opposed to open-pit mining, which typically gets deeper and expands in area over time, strip mining is a sequential operation with mining advancing in a given direction and tailings deposition and rehabilitation following closely behind.

Topsoil is removed at the leading edge and stockpiled. Overburden is then removed, commonly to multiple destinations. Mineral extraction follows not far behind overburden stripping. Depending on operational timing, overburden is preferably moved to its final destination either immediately behind mineral extraction or to cover tailings deposited into cellular areas within previous mineral extraction areas. The latter is subject to operational timing constraints such as the trafficability of the tailings cell areas for 
rehabilitation. Should overburden require temporary storage as surface stockpiles, the mining footprint increases and additional costs may be incurred due to double-handling the material.

The ongoing sequence described is illustrated in Figure 1.

Direction of Mining Advance:

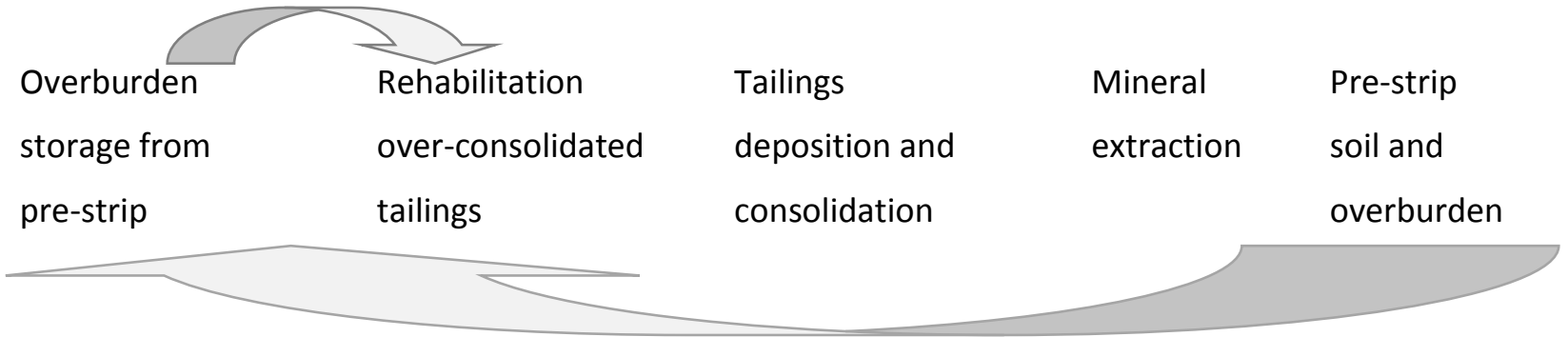

\section{Figure 1 Schematic mineral sands strip mining sequence}

A critical timing factor is therefore the readiness of consolidated tailings for safe rehabilitation operations.

The challenge at this site is associated with a 'social license to operate' requiring full rehabilitation within a relatively short time-frame in order to return the land to original agricultural use. From the regulatory perspective, such a requirement avoids the risk of an accumulating rehabilitation liability. Being able to improve the relative rehabilitation performance of the old workings can provide the operator with significant benefits.

In this case, the client also required the results of the consolidation modelling to evaluate the implications of the testing upon alternate mining configurations. Three alternate length options for the tailings deposition cell (within the advancing operation) were specified by the client as follows:

- Scenario A-400 m long cells (current practice).

- Scenario B-600 m long cells.

- Scenario C - $200 \mathrm{~m}$ long cells.

As can be seen, for a given mining width, the length of the internal tailings cell affects deposition volume, rate of rise and, most importantly, time, before rehabilitation commences over a typical 18 metre depth of tailings.

\subsubsection{Mineral sands tailings testing}

The tailings comprised a gap graded sample, consisting of approximately $86 \%$ sand and $14 \%$ fine silt and clay, with negligible coarse silt fraction. Slurry is deposited at approximately $50 \%$ solids by mass. Work comprised slurry consolidometer testing on a client-supplied slurry sample at a solids density typical of general site operating conditions. Testing was undertaken at four treatment dosages specified by the client and known respectively as untreated, low, medium and high polymer doses.

The concept of 'ageing', whereby the surface chemistry of mineral grains changes through oxidation and other means over relatively short timeframes, may be familiar to those involved with thickener operations. For this reason, flocculant and polymer screening are often conducted onsite using fresh tailings. In this case, when samples arrived at the Golder laboratory, it was noted that treatment did not replicate the results from screening conducted onsite. It was therefore decided to conduct the treatment onsite, prior to transporting the samples for laboratory testing.

On the basis of the significant permeability differences observed in testing between untreated and treated materials (outlined below), a particle size assessment of each sample was conducted using wet sieving. This indicated that the samples provided were not identical in gradation, as illustrated in Table 3. 


\section{Table 3 Wet sieving results}

\begin{tabular}{ccc}
\hline Sample & \% passing $75 \mu \mathrm{m}$ & \% passing $\mathbf{3 8} \boldsymbol{\mu m}$ \\
\hline Untreated & 14 & 13.6 \\
High-dose & 13.8 & 13.3 \\
Mid-dose & 12.5 & 12 \\
Low-dose & 10.5 & 10.1 \\
\hline
\end{tabular}

The data suggest that site-based sample preparation may have led to loss of fines in treated samples compared to untreated. This is counter-intuitive, as treatment generally improves fines capture, reducing segregation. In this case, it was realised that only the treated samples were decanted onsite, and that it was likely that a loss of fines had only occurred in treated samples, the extent of which was related to dosage. Therefore, some of the differences in behaviour may be attributed to sample difference. Further analysis of the fines fraction of each sample is to be undertaken to assess if this may be playing a role in the consolidation differences observed.

The results of laboratory testing indicated the following:

- Polymer treatment was seen to result in nearly immediate increases of density from $50 \%$ to between 55 and $58 \%$ solids. The increase in density for a sample without polymer was much slower, requiring approximately one month to achieve $55 \%$ solids.

- Polymer-treated materials exhibited significantly higher permeability, and therefore rate of consolidation, when compared to untreated materials. This is illustrated in Figure 2.

- The density achieved at the end of each consolidation stage for polymer treated samples was relatively similar. Ultimately, untreated materials achieved slightly higher densities. However, the ultimate density advantage is minor relative to the time related performance. The low-dose material achieved the lowest density, but the authors consider this is most likely related the lower fines content, itself most likely related to fines loss during decantation.

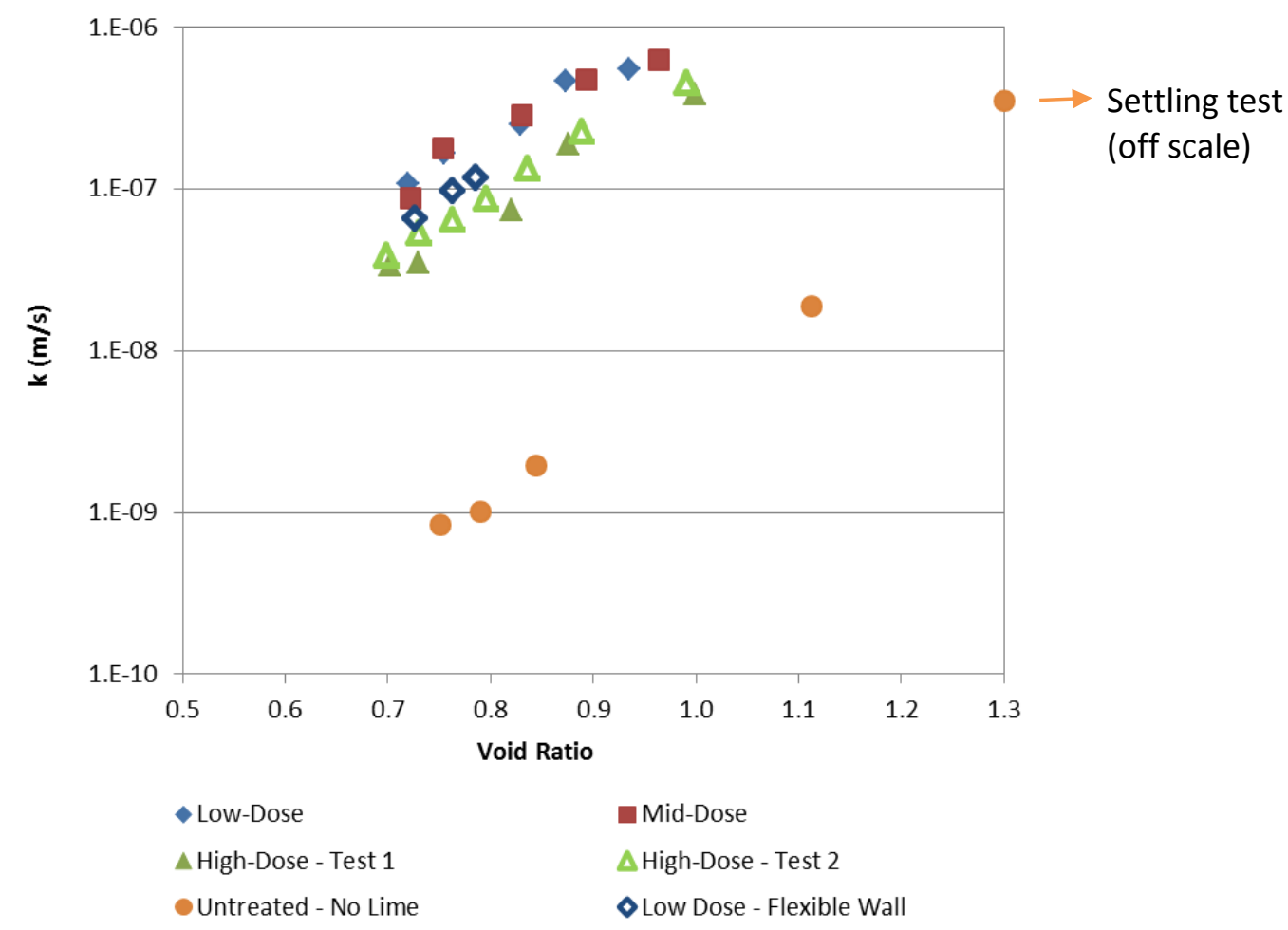

Figure 2 Permeability versus void ratio 
The results presented above suggest that polymer treatment results in significant changes to permeability, and hence to rate of consolidation. To the authors' knowledge, the differences observed for this sample are larger than any that have been observed following polymer treatment. Owing to the significant differences observed, further checks were undertaken as follows:

- A duplicate test was undertaken on the high-dose sample with very similar results, as indicated by data-points labelled High-Dose Tests 1 and 2 in Figure 2.

- A flexible wall permeameter test was undertaken. The flexible wall form of test was selected to assess if the macro-scale fabric induced by treatment resulted in preferential pathways for flow between the tailings and the rigid sidewalls of the slurry consolidometer. The results obtained were slightly lower than the slurry consolidometer test, but probably within the range of accuracy typically expected for permeability testing.

- The fines content of the top and bottom of the untreated sample were measured in order to assess if the material had segregated during pouring into the cell. Such segregation could result in a lower permeability fine-grained layer at the top of the cell, which would inhibit flow. No difference in gradation was observed. This was consistent with visual observation of a settling test on untreated material, where segregation was not apparent.

\subsubsection{Mineral sands tailings modelling}

To assess the implications of polymer treatment on the deposition time into a tailings cell and the potential time required for rehabilitation, consolidation modelling was undertaken on two scenarios, as outlined in Table 4.

It is noted that for the hypothetical untreated material deposition scenario, settling tests did not reach a final density during the time available for the test program. Therefore, it is expected that the low settling rate will inhibit the initiation of the development of effective stresses, were the material to be deposited at the rates considered in this study. To enable modelling using CONDESO, it was assumed that the behaviour of the material from deposition can be modelled using the concepts of effective stress, based on permeability estimates developed from settling and consolidation tests. The limitations of this approach are acknowledged.

\section{Table 4 ETD treated versus untreated}

\begin{tabular}{cccc}
\hline Measure & Unit & Polymer-treated & Untreated \\
\hline Filling time & days & 111 & 60 \\
Slurry volume deposited & $\mathrm{m}^{3}$ & 44,400 & 23,800 \\
Time for evaporative consolidation to commence & days & 130 & 500 \\
Post-depositional settlement & $\mathrm{m}$ & 0.20 & 5.7 \\
\hline
\end{tabular}

Incremental filling of the tailings in the consolidation model allowed the time required to fill a cell with polymer treated and untreated material to be assessed. Owing to the rapid initial dewatering resulting from polymer treatment, and increased rates of consolidation, a significantly greater quantity of material can be deposited into an idealised cell.

To assess the time required following deposition for rehabilitation to commence, settlement in the consolidation model was monitored, following the end of the completion of deposition until the settlement rate fell below the average rate of evaporation for the site. It has been proposed (e.g. Seneviratne et al. 1996) that as the rate of water reporting to the surface becomes less than the evaporation rate, suctions will begin to develop in the surface of the tailings. The time for this to occur provides a criterion to enable comparison of different scenarios, in the context of likely rehabilitation times. 
The lower rates of initial dewatering and consolidation observed for untreated material result in an idealised cell reaching capacity significantly more rapidly than for polymer-treated material. Furthermore, the minimal advancement of consolidation during deposition of untreated material results in a significantly longer time following deposition before evaporative consolidation commences. This is illustrated in Figure 4. In addition, post-deposition settlement is considerably greater. The magnitude of the differences is such that it is difficult to plot the post-deposition results for both models together.

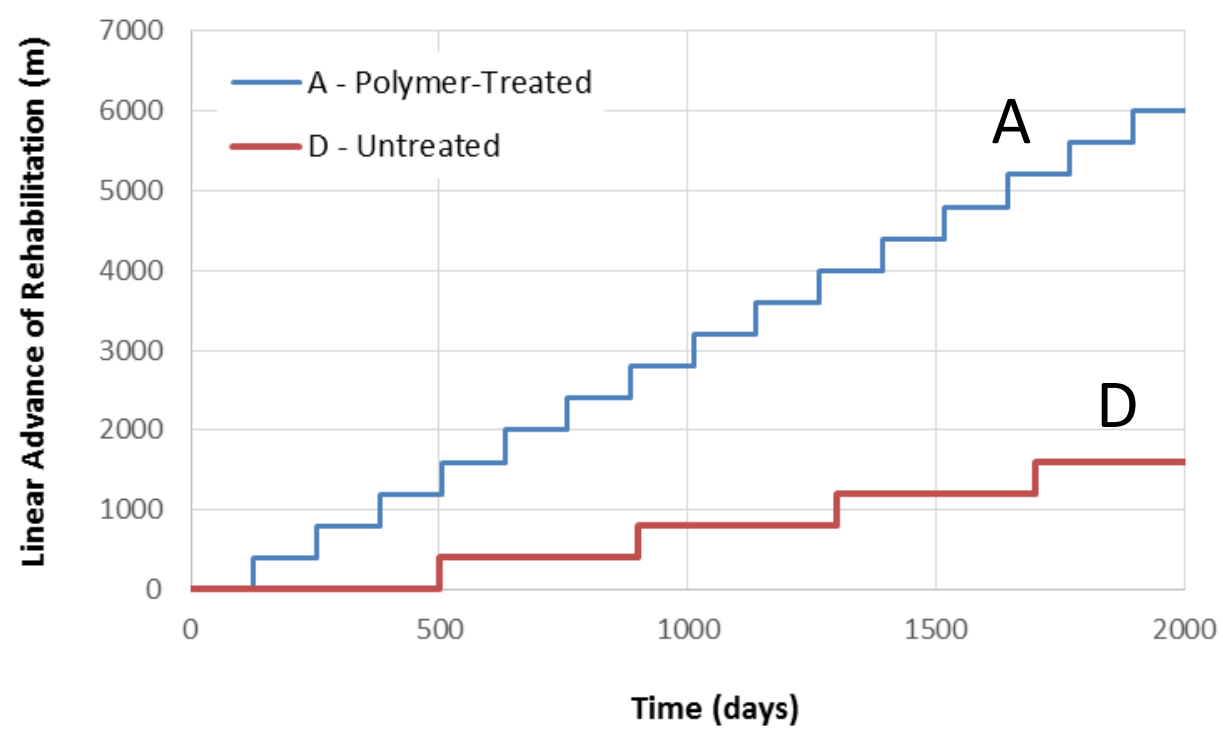

Figure 3 Rehabilitation advance rate - treated versus untreated

\subsubsection{Summary for mineral sands tailings project}

The results suggest that polymer treatment has the potential to significantly improve the overall performance of this type of mining operation, with particular benefit in the timely rehabilitation of mining land to agriculture. Furthermore, modelling suggests that the mining process could be optimised to the treatment by use of longer tailings cell sizes within the strip mining process; however, this aspect of the project is the subject of a parallel paper (Beveridge et al. 2015).

\subsection{A copper/gold mining operation}

\subsubsection{Site description}

The site utilises conventional cellular TSF design in an arid climate, and is constrained to some extent by water supply. The driver for improvement at this operation was considered likely to be a combination of improved water return and deferral of ongoing TSF embankment construction costs.

\subsubsection{Copper/gold mine tailings testing}

The tailings comprised fine material with $77 \%$ passing $75 \mu \mathrm{m}$ and $11 \%$ passing $2 \mu \mathrm{m}$. Work comprised settling and slurry consolidometer testing on a client-supplied slurry sample at a $60 \%$ solids density typical of general site operating conditions. Testing was undertaken on untreated slurry and at polymer doses of 15,60 and $105 \mathrm{~g} / \mathrm{t}$ respectively.

Slurry settling tests indicated that untreated tailings achieved slightly higher final dry density, typically by around $1-2 \%$, as indicated in Table 5 . However, given that the time taken to achieve the final $5 \%$ of density increase was significant, it was decided that a more useful measure of settling rate could be made on the basis of time to achieve $95 \%$ of final settled density. The results of the comparison using this metric are presented in Table 6. 
Table 5 Settling tests - final dry density achieved $\left(t / \mathrm{m}^{3}\right)$

\begin{tabular}{ccccc}
\hline & Undrained & Top drained & Bottom drained & Top and bottom drained \\
\hline Untreated & 1.15 & 1.15 & 1.28 & 1.31 \\
15 & 1.13 & 1.15 & 1.25 & 1.30 \\
60 & 1.12 & 1.10 & 1.26 & 1.23 \\
105 & 1.10 & 1.11 & 1.24 & 1.25 \\
\hline
\end{tabular}

Table 6 Settling tests - time to $95 \%$ of final density (days)

\begin{tabular}{ccccc}
\hline & Undrained & Top drained & Bottom drained & Top and bottom drained \\
\hline Untreated & 2.60 & 2.60 & 5.00 & 5.80 \\
15 & 1.40 & 1.80 & 3.90 & 5.30 \\
60 & 0.99 & 0.47 & 1.70 & 1.40 \\
105 & 0.12 & 0.12 & 1.80 & 1.70 \\
\hline
\end{tabular}

The settling test data clearly indicated a significant increase in the settling rate, typically three times faster when treated at a dose rate of $60 \mathrm{~g} / \mathrm{t}$. Example results for the undrained settling tests are presented graphically in Figure 4.

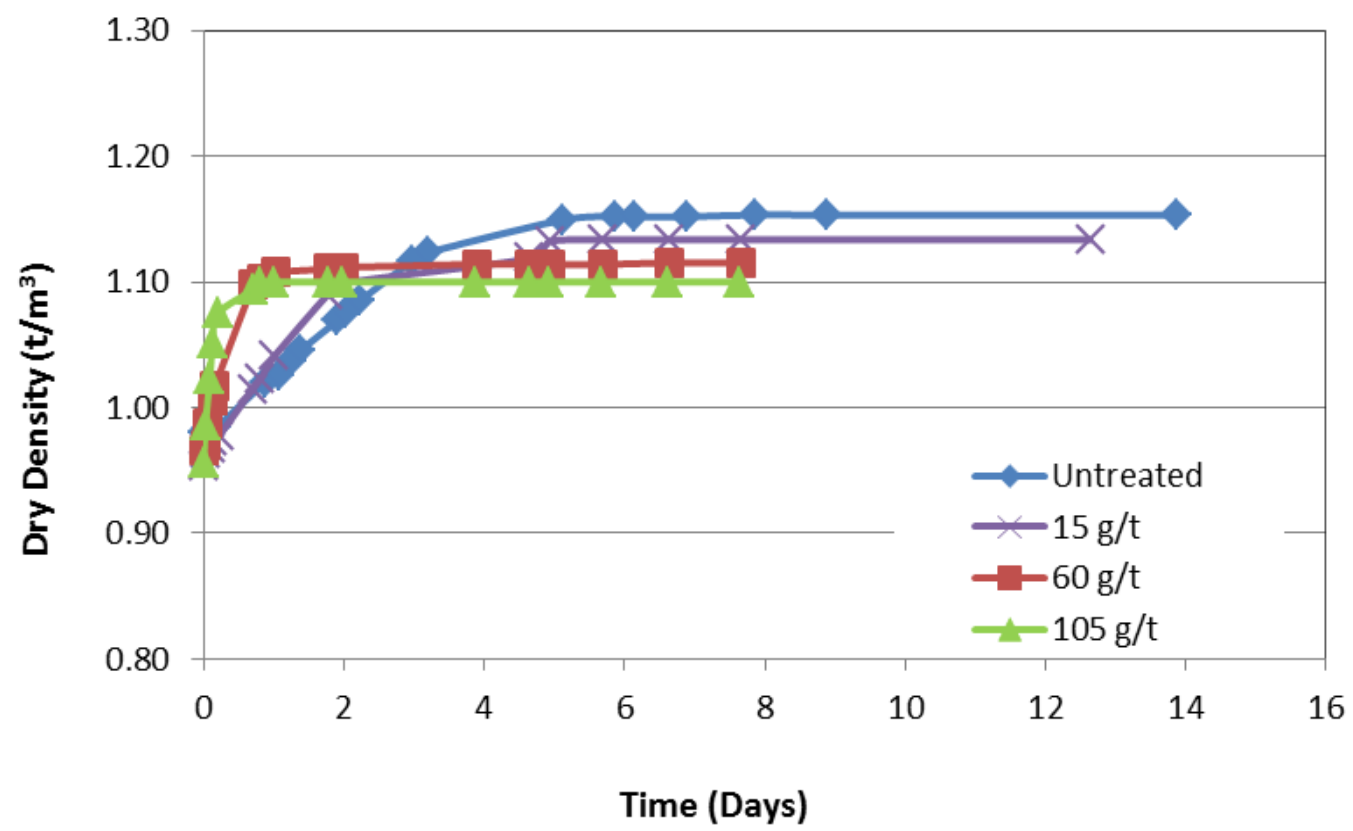

\section{Figure 4 Settling test comparison - undrained tests}

Whilst the settling tests illustrate a marked change in performance, the untreated material was achieving parity in the two to three day timeframe. In terms of any early signs of a potential business improvement, the results were perhaps best described as underwhelming.

The settling tests were followed by slurry consolidometer tests, the results of which are presented in Figure 5, which shows the variation in final dry density across a plot for comparison to the densities achieved through consolidation. Final dry density tends to decrease slightly with increasing polymer dosage, being approximately $3 \%$ lower at $100 \mathrm{kPa}$ vertical effective stress for $60 \mathrm{~g} / \mathrm{t}$ material. However, permeability and rate of consolidation are approximately double. On the basis of these effects, it was not 
immediately clear to what extent a faster rate of consolidation for polymer treated samples might outweigh the higher final dry density of untreated material. This was assessed through consolidation modelling, as outlined in Figure 5.

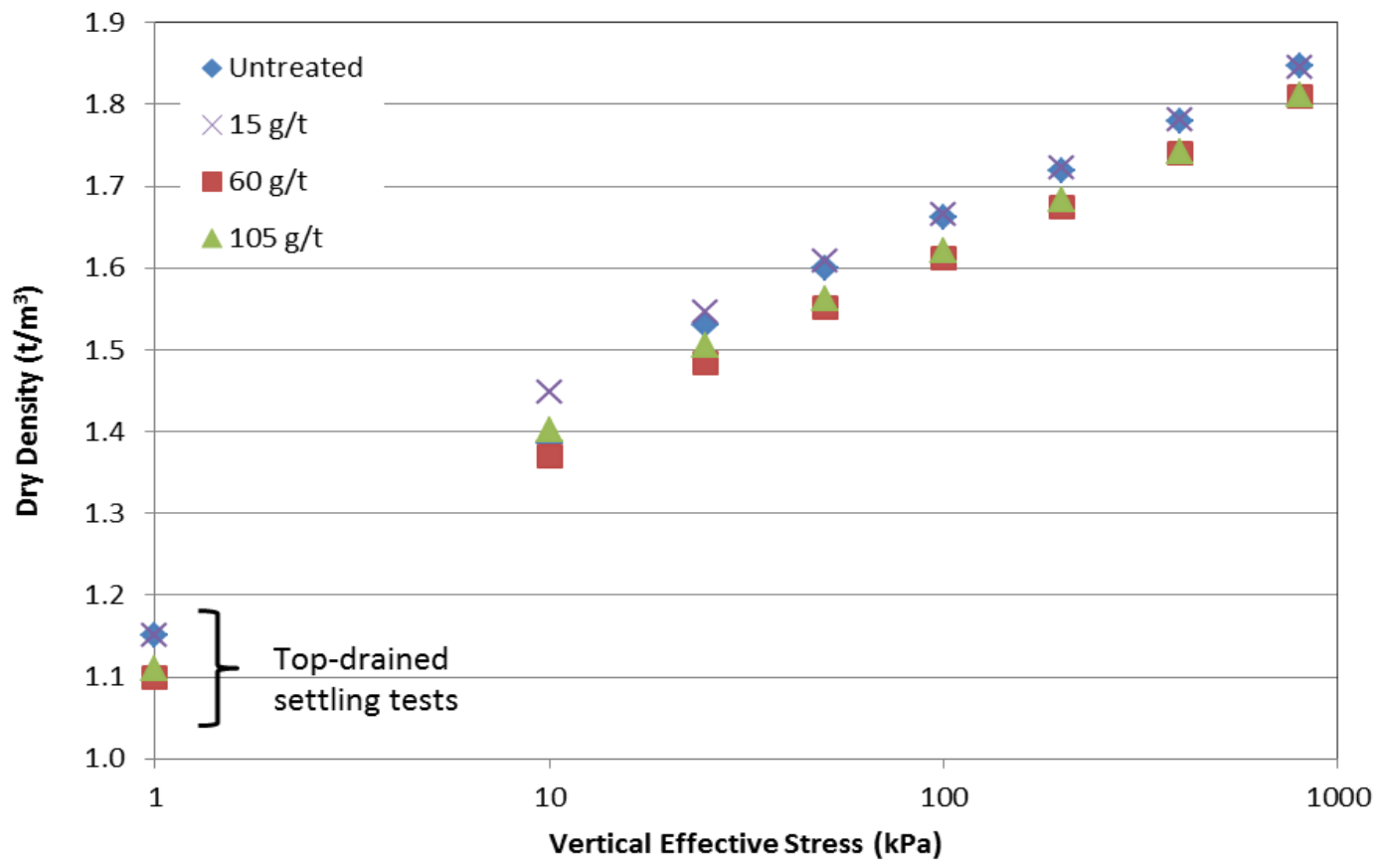

Figure 5 Final consolidated density versus vertical effective stress

\subsubsection{Copper/gold tailings modelling}

The Client indicated that in situ rates of rise ranging from approximately $6-35 \mathrm{~m} / \mathrm{y}$ are potentially relevant to TSF operations. Cognisance has been taken of this range when selecting depositional rates of rise for input to CONDESO modelling. The results are presented in Table 7, for predicted rate of rise, average dry density and estimated potential water recovery for the untreated and $60 \mathrm{~g} / \mathrm{t}$ treated datasets.

The estimated rates of rise are presented in Figure 6. Depositional and field rate of rise were defined in Section 2.2.

Table 7 Consolidation model results

\begin{tabular}{ccccccc}
\hline $\begin{array}{c}\text { Depositional } \\
\text { rate of rise }\end{array}$ & \multicolumn{2}{c}{$\begin{array}{c}\text { Average in situ rate of rise } \\
\text { predicted }(\mathbf{m} / \mathbf{y})\end{array}$} & \multicolumn{2}{c}{$\begin{array}{c}\text { Estimated average dry } \\
\text { density }\left(\mathbf{t} / \mathbf{m}^{3}\right)\end{array}$} & \multicolumn{2}{c}{$\begin{array}{c}\text { Estimated potential water } \\
\text { recovery }(\%)\end{array}$} \\
& Untreated & $\mathbf{6 0} \mathbf{g} / \mathbf{t}$ & Untreated & $\mathbf{6 0} \mathbf{g} / \mathbf{t}$ & Untreated & $\mathbf{6 0} \mathbf{g} / \mathbf{t}$ \\
\hline 10 & 6.8 & 6.8 & 1.41 & 1.40 & $45.8 \%$ & $45.3 \%$ \\
25 & 19 & 17.5 & 1.31 & 1.36 & $38.5 \%$ & $43 \%$ \\
35 & 27.2 & 24.8 & 1.26 & 1.31 & $33.8 \%$ & $38.9 \%$ \\
\hline
\end{tabular}




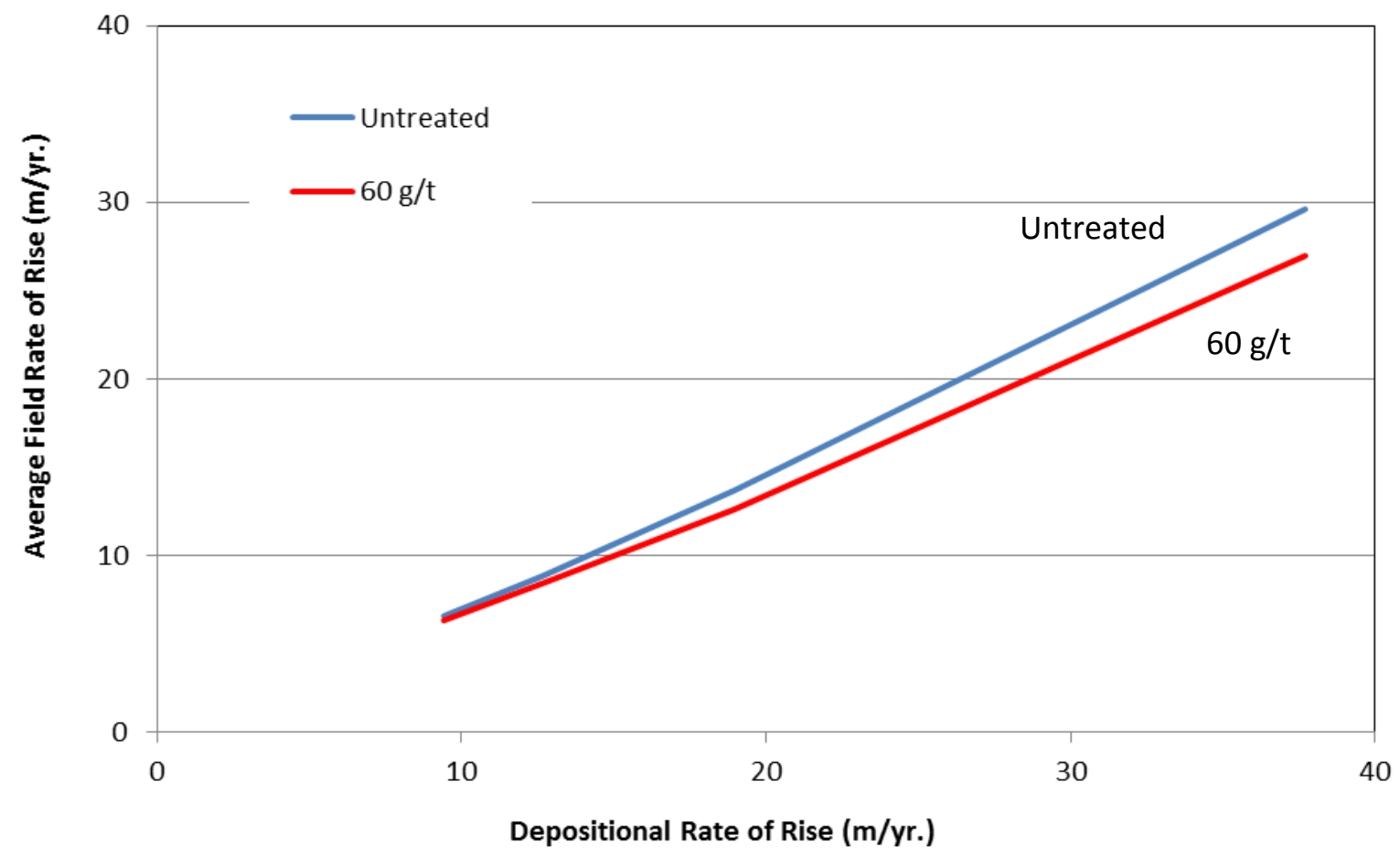

Figure 6 Interaction between depositional and predicted in situ rates of rise

The modelling suggests that performance improvement would only potentially occur at high depositional rates of rise. Even when a benefit is observed from treatment in this instance, the difference compared to untreated material is minimal. This result, coupled with likely operational costs of polymer treatment, was not particularly encouraging.

\subsubsection{Summary for copper mine tailings project}

The results suggest that polymer treatment is unlikely to be a strong contender for a business improvement project at this site. The results appear to offer modest potential benefits only at very high rates of rise. The authors are not, however, aware of the full details of site challenges, which were not part of this scoping level study.

\section{Conclusions}

Although all three scoping level studies demonstrated potential improvements for tailings deposition, only two were considered as likely candidates for further study.

Results for the copper mining operation suggest that polymer treatment may reduce the in situ rate of rise from 3.0 to $2.2 \mathrm{~m} / \mathrm{y}$ over a 10 -year period, a $26 \%$ saving in the effective utilisation of constructed storage volume.

Results for the mineral sands operation suggest that treatment has the potential to significantly improve the overall performance of this type of business, with particular benefit in the timely rehabilitation of mining land to agriculture. Furthermore, modelling suggests that the mining process could be optimised to tailings treatment by use of longer tailings cell sizes within the strip mining process.

Results for the copper/gold mining operation were unconvincing in terms of potential economics as a business improvement project.

Overall, the authors consider that this work reinforces the need for careful assessment of the site-specific operational constraints that may form part of a potential business case, and ensure that the testing and interpretation are tailored to address relevant opportunities. 


\section{Acknowledgement}

The authors would like to thank Martin Edgar of BASF and David Williams of Golder for their input to these projects and their support for this type of work.

\section{References}

Adkins, S, Flanagan, IJ, Lamperd, J \& Rose, S 2007 'A novel approach to dry stacking and land rehabilitation using Ciba ${ }^{\circledR} \mathrm{Rheomax}^{\mathrm{TM}}$ ETD Technology', in AB Fourie \& RJ Jewell (eds), Proceedings of the Tenth International Seminar on Paste and Thickened Tailings, Australian Centre for Geomechanics, Perth, pp. 295-304.

Amarasinghe, PM, Katti, KS, \& Katti, DR 2012, 'Insight into role of clay-fluid molecular interactions on permeability and consolidation behaviour of Na-montmorillonite swelling clay', Journal of Geotechnical and Geoenvironmental Engineering, vol. 138 , no. 2 , pp. 138-146.

Azam, S 2011, 'Large strain behaviour of polymer-amended laterite slurries', International Journal of Geomechanics, vol. 11, no. 2, pp. 105-112.

Beveridge, A, Mutz, P \& Reid, D 2015, 'Tailings co-disposal case study; Art or science?', in RJ Jewell \& AB Fourie (eds), Proceedings of 18th International Seminar on Paste and Thickened Tailings, Australian Centre for Geomechanics, Perth, pp. 507-522.

Brumby, M, Brough, J \& Flanagan, I 2008, 'Rheomax ${ }^{\mathrm{TM}}$ modified tailings disposal at Welbeck Colliery', in AB Fourie, RJ Jewell, P Slatter \& A Patterson (eds), Proceedings of the 11th International Seminar on Paste and Thickened Tailings, Australian Centre for Geomechanics, Perth, pp. 199-210.

Chang, N, Heymann, G \& Clayton, C 2011, 'The effect of fabric on the behaviour of gold tailings', Géotechnique, vol. 61, no. 3, pp. 187-197.

da Silva, F 2011, 'Reducing risks to tailing storage facilities through in-line flocculant addition,' in J Han \& DA Alzamora (eds), Geo-Frontiers 2011: Advances in Geotechnical Engineering, American Society of Civil Engineers, Reston.

Daubermann, R \& Földvári, Z 2008, 'Ciba ${ }^{\circledR}$ Rheomax ${ }^{\text {TM }}$ ETD technology evaluation on chrome thickener underflow for enhanced tailings management', in AB Fourie, RJ Jewell, P Slatter \& A Patterson (eds), Proceedings of the $11^{\text {th }}$ International Seminar on Paste and Thickened Tailings, Australian Centre for Geomechanics, Perth, pp. 377-384.

Daubermann, R \& Földvári, Z 2009, 'Evaluation of Ciba ${ }^{\circledR}$ Rheomax ${ }^{\mathrm{TM}}$ chemical technology on ferrochrome deposits in concrete-lined tailings dams', in AB Fourie, RJ Jewell, S Barrera \& J Wiertz (eds), Proceedings of the 12th International Symposium on Paste and Thickened Tailings, Australian Centre for Geomechanics, Perth, pp. 39-46.

Dymond, B 2003, 'Enhanced tailings management solutions', Proceedings of the 6th International Seminar on Paste and Thickened Tailings, Australian Centre of Geomechanics, Perth.

Inparajah, D \& Wong, RCK 2008, '1-D Consolidation characteristics of kaolinite-bentonite mixtures with different pore fluid salinity', Proceedings of the 61st Canadian Geotechnical Conference, Canadian Geotechnical Society, Richmond and International Association of Hydrogeologists: Canadian National Chapter.

Jeeravipoolvarn, S, Scott, JD \& Chalaturnyk, RJ 2009, 'Geotechnical characterisitics of laboratory in-line thickened oil sands tailings', Proceedings of the Thirteenth International Conference on Tailings and Mine Waste, University of Alberta Geotechnical Center, Edmonton.

Jeeravipoolvarn, S, Scott, JD \& Chalaturnyk, RJ 2010, 'Composite tailings made from in-line thickened oil sands tailings', Proceedings of the 2nd International Oil Sands Conference, pp. 337-347.

Kaiser, LK, Lamperd, JW, Load, C \& Cooling, DJ 2006, 'A new approach to bauxite residue stacking: utilizing Ciba ${ }^{\circledR}$ RHEOMAX ${ }^{\mathrm{TM}}$ ETD Technology', in RJ Jewell, S Lawson \& P Newman (eds.) Proceedings of 9th International Seminar on Paste and Thickened Tailings, Limerick, Ireland, Australia Centre of Geomechanics, Perth, pp. 57-68.

Matthew, PK \& Narasimha, SR 1997, 'Influence of cations on compressibility behavior of a marine clay', Journal of Geotechnical and Geoenvironmental Engineering, vol. 123, no. 11, pp. 2071-1073.

Pillai, RJ, Robinson, RG \& Boominathan, A 2011, 'Effect of microfabric on undrained static and cyclic behaviour of kaolin clay', Journal of Geotechnical and Geoenvironmental Engineering, vol. 137, no. 4, pp. 421-430.

Reid, D \& Fourie, AB 2012, 'The effects of "in-line" flocculation on the geotechnical properties of clay tailings', Proceedings of Tailings and Mine Waste '12, University of British Columbia, Vancouver.

Reid, D \& Fourie, AB 2014, 'Use of CPTu to assess sensitivity of a polymer-treated slurry', Proceedings of the 3rd International Symposium on Cone Penetration Testing, pp. 439-448.

Riley, T \& Utting, L 2014, 'Polymer-modified tailings deposition - a management perspective', in RJ Jewell, AB Fourie, PS Wells \& D van Zyl (eds), Proceedings of the 17th International Seminar on Paste and Thickened Tailings, InfoMine Inc., Vancouver, pp. 179-186.

Sachan, A \& Penumadu, D 2007, 'Effect of microfabric on shear behaviour of kaolin clay', Journal of Geotechnical and Geoenvironmental Engineering, vol. 133, no. 3, pp. 306-318.

Schiffman, RL, Pane, V \& Gibson, RE 1984, 'The theory of one-dimensional consolidation of saturated clays IV: an overview of non-linear finite strain sedimentation and consolidation', in RN Yong \& FC Townsend, Proceedings of the ASCE Symposium on Sedimentation / Consolidation Models, American Society of Civil Engineers, San Francisco, pp. 1-29.

Seneviratne, NH, Fahey, M, Newson, TA \& Fujiyasu, Y 1996, 'Numerical modelling of consolidation and evaporation of slurried mine tailings', International Journal for Numerical and Analytical Methods in Geomechanics, vol. 20, no. 9, pp. 647-671.

Sheeran, DE \& Krizek, RJ 1971, 'Preparation of homogenous soils samples by slurry consolidation', Journal of Materials ASTM, vol. 6 , no. 2 , pp. 356-373. 
Vietti, AJ, Cooke, R, Ntshabele, K, Cooks, M \& Busani, B 2008, 'Rheomax ${ }^{\mathrm{TM}}$ and water conservation at Orapa Mine', in AB Fourie, RJ Jewell, PT Slatter \& A Paterson, Proceedings of the 11th International Seminar on Paste and Thickened Tailings, Australian Centre for Geomechanics, Perth, pp. 353-364.

Wang, YH \& Siu, WK 2006, 'Structure characteristics and mechanical properties of kaolinite soils. II, effects of structure on mechanical properties', Canadian Geotechnical Journal, vol. 43, no. 6, pp. 601-617.

Wells, P, Revington, A \& Omotoso, O 2011, 'Mature fine tailings drying - technology update', in RJ Jewell \& AB Fourie, Proceedings of the 14th International Seminar on Paste and Thickened Tailings, Australian Centre for Geomechanics, Perth, pp. 155-166.

Yao, D \& Znidarcic, D 1997, Crust formation and dessication characteristics for phosphatic clays: user's manual for computer program CONDESO, Florida Institute of Phosphate Research, Polk Country.

Yao, Y 2012, 'The effect of flocculant on the geotechnical properties of mature fine tailings: an experimental study', Proceedings of the 3rd International Oil Sands Conference, pp. 391-398. 